\title{
Fungicide Resistance Management Guidelines for Cucurbit Downy and Powdery Mildew Control in the Mid-Atlantic and Northeast Regions of the United States in 2018
}

Christian A. Wyenandt, ${ }^{\dagger}$ Department of Plant Biology, Rutgers University, New Jersey Agricultural Experiment Station, Rutgers Agricultural Research and Extension Center, Bridgeton, NJ 08302; Margaret T. McGrath, Plant Pathology and Plant-Microbe Biology Section, Long Island Horticultural Research and Extension Center, Cornell University, Riverhead, NY 11901; Kathryne L. Everts, Department of Plant Sciences and Landscape Architecture, University of Maryland/Department of Plant and Soil Sciences, University of Delaware, Lower Eastern Shore Research and Education Center, Salisbury, 21801; Steven L. Rideout, Virginia Polytechnic Institute and State University, Eastern Shore Agricultural Research and Extension Center, Painter, 23420; Beth K. Gugino, Department of Plant Pathology and Environmental Biology, Pennsylvania State University, University Park, 16802; and Nathan Kleczewski, Department of Plant and Soil Sciences, University of Delaware, Newark, 19707

Accepted for publication 14 December 2017.

In the mid-Atlantic and Northeast regions of the United States, approximately 17,500 farms produce vegetable crops annually with a value of more than $\$ 1.2$ billion (NASS 2012). Over 60,000 acres of cucurbit crops were grown in both regions in 2012 (NASS 2012). In recent years, several new fungicide chemistries and modes-ofaction (MOAs) labeled for use in vegetable production have been registered in the United States. Many of these fungicides have MOAs that target pathogen development at a single site. Fungicides with a single-site MOA are often considered at high risk for the development of fungal resistance and possess a much greater risk for resistance development than fungicides with multiple MOAs (i.e., protectant fungicides such as chlorothalonil). In the mid-Atlantic region in recent years, fungicide resistance has developed in important cucurbit pathogens, such as Podosphaera (sect. Sphaerotheca) xanthii (Castagne) U. Braun \& Shishkoff causing powdery mildew (McGrath 2001; McGrath and Wyenandt 2017; Wyenandt et al. 2008) and Didymella bryoniae (Auersw.) Rehm causing gummy stem blight in watermelon (Everts 1999).

Since 2007, a fungicide resistance management guide has been available to vegetable growers in the mid-Atlantic region to help manage resistance development (Wyenandt et al. 2009b). Now in its 12th edition, over 25,000 hard copies of these guidelines have been distributed to cucurbit growers in the mid-Atlantic and Northeast regions (Wyenandt, personal communication). The guide is now available online for free through a number of university websites in the region. In 2009, the first fungicide resistance management table for the control of cucurbit downy and powdery mildew was developed (Wyenandt et al. 2009a). Since that time, there have been significant changes in the efficacy of some recommended fungicides and availability of new active ingredients for the control of both pathogens. The updated fungicide resistance management table consists of currently recommended fungicides listed for the control of cucurbit downy mildew and powdery mildew from commercial recommendations guides developed for the mid-Atlantic region (Pennsylvania, New Jersey, Delaware, Maryland, Virginia, and West

${ }^{\dagger}$ Corresponding author: Christian A. Wyenandt;

E-mail: wyenandt@aesop.rutgers.edu

(C) 2018 The American Phytopathological Society
Virginia), New York, and the Northeast region (Maine, New Hampshire, Vermont, Connecticut, Massachusetts, and Rhode Island). The table lists labeled fungicides, their active ingredient(s), Fungicide Resistance Action Committee (FRAC) and risk management codes, and resistance management guidelines (Table 1). In the updated table are 41 labeled fungicides that include 23 different FRAC codes with their corresponding codes for risk of resistance development ( $\mathrm{L}=$ low risk, $\mathrm{M}=$ medium risk, and $\mathrm{H}=$ high risk) established by FRAC (Table 1) (FRAC 2018). Importantly, the fungicides, active ingredients, and FRAC numbers are color-coordinated to help distinguish between fungicides belonging to the same FRAC code (i.e., similar MOAs). A superscript $\mathrm{R}$ next to the FRAC code indicates that resistance to that particular chemistry has been detected in the region. To denote if resistance management is required, a $\mathrm{Y}$ for yes or an $\mathrm{N}$ for no is listed (Table 1). Currently, 36 of 41 fungicides listed (88\%) require the use of resistance management strategies to help reduce the chances for resistance development. To date, resistance has been detected in 6 of the 23 FRAC codes $(1,3,4,7,11$, and U6) ( 22\%) listed for either cucurbit powdery mildew or downy mildew control in both regions, and poor control has been noted in some recently (e.g., FRAC codes 33, 40, and 43) (Table 1). The current anticipated efficacy of each fungicide is denoted by the use of a plus system in which one (+) designates little or poor fungicide efficacy, two $(++)$ equates poor to good efficacy, three (+++) designates good efficacy, four (++++) designates very good efficacy, and five $(+++++)$ equals excellent efficacy. If control failure has been detected to a fungicide, the designated (+) signs are colored red, emphasizing that a particular fungicide/pathogen combination may be at risk for resistance development (Table 1).

\section{Literature Cited}

Everts, K. L. 1999. First report of benomyl resistance in Didymella bryoniae in Delaware and Maryland. Plant Dis. 83:304.

Fungicide Resistance Action Committee (FRAC). 2018. Online. http://www. frac.info/publications/downloads

McGrath, M. T. 2001. Fungicide resistance in cucurbit powdery mildew: Experiences and challenges. Plant Dis. 85:236-245.

McGrath, M. T., and Wyenandt, C. A. 2017. First detection of boscalid resistance in Podosphaera xanthii in the United States with failure to control cucurbit powdery mildew in New York and New Jersey in 2009. Plant Health Prog. Online publication. doi.org/10.1094/PHP-03-17-0014-BR 


\begin{tabular}{|c|c|c|c|c|c|c|c|}
\hline \multirow[b]{2}{*}{ Fungicide } & \multirow[b]{2}{*}{ Active ingredient(s) } & \multirow[b]{2}{*}{$\begin{array}{l}\text { *0 } \\
0 \\
0 \\
0 \\
0 \\
\frac{\mathbb{L}}{4}\end{array}$} & \multirow[b]{2}{*}{ 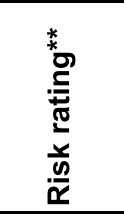 } & \multirow[b]{2}{*}{ 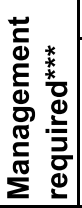 } & \multicolumn{2}{|c|}{ Efficacy ratings } & \multirow[b]{2}{*}{$\begin{array}{c}\text { General fungicide } \\
\text { resistance } \\
\text { management } \\
\text { guidelines } \\
\text { ga*** }\end{array}$} \\
\hline & & & & & $\begin{array}{l}\frac{\lambda}{0} \\
\frac{3}{0} \\
\substack{0 \\
0} \\
0 \\
0\end{array}$ & \气 & \\
\hline Kocide 3000 or OLF & Fixed copper(s) & M1 & $\mathrm{L}$ & $\mathbf{N}$ & + & & \multirow{4}{*}{$\begin{array}{l}\text { FRAC code } \mathrm{M} \text { fungicides are } \\
\text { low-risk, protectant fungi- } \\
\text { cides. Use alone, or tank } \\
\text { mix with high-risk fungicides } \\
\text { to improve control. }\end{array}$} \\
\hline Microthiol or OLF & Sulfur & M2 & L & $\mathrm{N}$ & ++ & & \\
\hline Manzate or OLF & EBDC & M3 & $\mathrm{L}$ & $\mathbf{N}$ & & ++ & \\
\hline Bravo or OLF & Chlorothalonil & M5 & $\mathrm{L}$ & $\mathrm{N}$ & ++ & ++ & \\
\hline Topsin M & Thiophanate methyl & 1 & $\mathrm{H}^{\mathrm{R}}$ & $\mathbf{Y}$ & + & & \multirow{10}{*}{$\begin{array}{l}\text { Select fungicides with at } \\
\text { least ++ rating. Rotate } \\
\text { among fungicides with } \\
\text { different FRAC codes. Tank } \\
\text { mix high-risk fungicides with } \\
\text { FRAC code M product if the } \\
\text { product is not formulated } \\
\text { with a FRAC code M } \\
\text { fungicide. }\end{array}$} \\
\hline Proline & Prothioconazole & 3 & $M^{R}$ & $\mathbf{Y}$ & ++++ & & \\
\hline Procure & Triflumizole & 3 & $\mathrm{M}^{\mathrm{R}}$ & $\bar{Y}$ & +++ & & \\
\hline Rally & Myclobutanil & 3 & $\mathrm{M}^{\mathrm{R}}$ & $\mathrm{Y}$ & +++ & & \\
\hline Folicur & Tebuconazole & 3 & $M^{R}$ & $\mathrm{Y}$ & ++ & & \\
\hline Rhyme & $\begin{array}{l}\text { Flutriafol } \\
\end{array}$ & 3 & $M^{R}$ & $\begin{array}{l} \\
Y\end{array}$ & ++ & & \\
\hline Inspire Super & Difenconazole + cyprodinil & $3+9$ & $M^{R}+M^{R}$ & $Y$ & + & & \\
\hline TopGuard EQ & Flutriafol + azoxystrobin & $3+11$ & $M^{R}+H^{R}$ & $\mathbf{Y}$ & ++++ & & \\
\hline Ridomil Gold Copper & Mefenoxam + copper & $4+M 1$ & $\mathrm{H}^{\mathrm{R}}+\mathrm{L}$ & 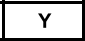 & & + & \\
\hline Ridomil Gold Bravo & Mefenoxam + chlorothalonil & $4+M 5$ & $H^{R}+\mathrm{L}$ & $\mathbf{Y}$ & & + & \\
\hline Fontelis & Penthiopyrad & 7 & $\mathrm{H}^{\mathrm{R}}$ & $\mathbf{Y}$ & + & & \multirow{7}{*}{$\begin{array}{l}\text { When resistance is } \\
\text { qualitative (FRAC code } 1 \\
\text { and } 11 \text { fungicides), resistant } \\
\text { pathogen isolates are } \\
\text { completely insensitive and } \\
\text { cannot be controlled with the } \\
\text { fungicide or another in the } \\
\text { group due to cross } \\
\text { resistance. }\end{array}$} \\
\hline Luna Experience & Fluopyram + tebuconazole & $7+3$ & $M-H+M^{R}$ & $Y$ & +++ & & \\
\hline Aprovia Top & Benzovindiflupyr + difenoconazole & $7+3$ & $M-H+M^{R}$ & $\mathbf{Y}$ & +++ & & \\
\hline Luna Sensation & Fluopyram + trifloxystrobin & $7+11$ & $\mathrm{M}-\mathrm{H}+\mathrm{H}^{\mathrm{R}}$ & $\mathrm{Y}$ & ++ & & \\
\hline Pristine & Boscalid + pyraclostrobin & $7+11$ & $M-H^{R}+H^{R}$ & $\mathbf{Y}$ & + & + & \\
\hline Quadris or OLF & Azoxystrobin & 11 & $\mathrm{H}^{\mathrm{R}}$ & $\mathrm{Y}$ & + & + & \\
\hline Cabrio & Pyraclostrobin & 11 & $\mathrm{H}^{\mathrm{R}}$ & $\mathbf{Y}$ & + & + & \\
\hline Flint & Trifloxystrobin & 11 & $\mathrm{H}^{\mathrm{R}}$ & $\mathbf{Y}$ & + & & \multirow{9}{*}{$\begin{array}{l}\text { With quantitative resistance } \\
\text { (FRAC Code } 3 \text { and } 7 \\
\text { fungicides), pathogen isolates } \\
\text { exhibit range in fungicide } \\
\text { sensitivity, and efficacy } \\
\text { depends on level of } \\
\text { insensitivity and inherent } \\
\text { activity of the active } \\
\text { ingredient. Control may be } \\
\text { obtained with most active } \\
\text { chemistry, high label rates, } \\
\text { and tight spray intervals. } \\
\end{array}$} \\
\hline Reason & Fenamidone & 11 & $\mathrm{H}^{\mathrm{R}}$ & $Y$ & & + & \\
\hline Tanos & Famoxadone + cymoxanil & $11+27$ & $\mathrm{H}+\mathrm{L}-\mathrm{M}$ & $Y$ & & + & \\
\hline Quintec $^{\mathrm{a}}$ & Quinoxyfen & 13 & $\mathrm{M}^{\mathrm{R}}$ & $Y$ & +++++ & & \\
\hline Ranman & Cyazofamid & 21 & $\mathrm{M}-\mathrm{H}$ & $Y$ & & +++ & \\
\hline Gavel & Zoxamide + mancozeb & $22+M 3$ & L-M + L & $\mathbf{Y}$ & & ++ & \\
\hline Zing! & Zoxamide + chlorothalonil & $22+M 5$ & $L-M+L$ & $\mathbf{Y}$ & & ++ & \\
\hline Curzate & Cymoxanil & 27 & $L-M$ & $\mathbf{Y}$ & & ++ & \\
\hline Ariston & Cymoxanil + chlorothalonil & $27+M 5$ & $\mathrm{~L}-\mathrm{M}+\mathrm{L}$ & $\mathbf{Y}$ & & ++ & \\
\hline Previcur Flex ${ }^{b}$ & Propamocarb HCL & 28 & $\mathrm{~L}-\mathrm{M}$ & $Y$ & & $+/+++$ & \multirow{6}{*}{$\begin{array}{l}{ }^{2} \text { While resistance to Quintec } \\
\text { has been confirmed, impact } \\
\text { on control has not yet been } \\
\text { documented, likely reflecting } \\
\text { low numbers of resistant } \\
\text { strains present. Use } \\
\text { sparingly. }\end{array}$} \\
\hline Omega & Fluazinam & 29 & $\mathrm{~L}$ & $\mathbf{N}$ & & +++ & \\
\hline Alliete & Aluminum tris & 33 & $\mathrm{~L}^{\mathrm{R}}$ & $Y$ & & + & \\
\hline Phosphonates & Phosphorous acid salts & 33 & $\mathrm{~L}^{\mathrm{R}}$ & $\begin{array}{r} \\
\end{array}$ & & + & \\
\hline Forum $^{\mathrm{b}}$ & Dimethomorph & 40 & $L-M^{R}$ & $\mathrm{Y}$ & & + & \\
\hline Revus $^{\mathrm{b}}$ & Mandipropamid & 40 & $L-M^{R}$ & $\mathrm{Y}$ & & $+/+++$ & \\
\hline Presidio $^{b}$ & Fluopicolide & 43 & $\mathrm{H}$ & $\mathrm{Y}$ & & $+/++++$ & \multirow{5}{*}{$\begin{array}{l}{ }^{\mathrm{b}} \text { Revus is poor on } \\
\text { cucumber. Presidio, Previcur } \\
\text { Flex, and Forum have } \\
\text { exhibited poor control in } \\
\text { some recent fungicide } \\
\text { evaluations. }\end{array}$} \\
\hline Zampro & Ametoctradin + dimethomorph & $45+40$ & $M-H+L-M^{R}$ & Y & & $+/+++$ & \\
\hline Orondis Ultra & Oxathiapiprolin + mandipropamid & 49 & $H+L-M^{R}$ & $\mathbf{Y}$ & & +++++ & \\
\hline Torino & Cyflufenamid & $\mathrm{U} 6$ & $\mathrm{M}^{\mathrm{R}}$ & $\mathrm{Y}$ & $+/++++$ & & \\
\hline Vivando & Metrafenone & U8 & $M$ & 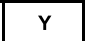 & +++++ & & \\
\hline
\end{tabular}

Efficacy ratings: $+=$ poor (not recommended) $++=$ poor to good, $+++=$ good, $++++=$ very good, and $+++++=$ excellent; red font indicates control failures detected in the mid-Atlantic and Northeast regions.

* FRAC code: $\mathrm{M}$ = multisite mode of action (MOA); numbered groups = fungicides with similar MOA; fungicides with the same number or color belong to the same FRAC code.

** Risk ratings: $\mathrm{L}=$ low risk, $\mathrm{M}=$ moderate risk, and $\mathrm{H}=$ high risk for fungicide resistance to develop; ${ }^{\mathrm{R}}=$ resistance known to develop according to Fungicide Resistance Action Committee (FRAC 2018).

*** Risk management required according to fungicide label.

**** See fungicide label for specific crops, rates, and instructions on use.

Trade or brand names disclaimer: The trade or brand names given herein are supplied with the understanding that no discrimination is intended and no endorsement by the Cooperative Extension is implied. Furthermore, in some instances the same compound may be sold under different names, which may vary as to label clearances. 
National Agricultural Statistics Service (NASS). 2012. Online. http://www.nass. usda.gov/

Wyenandt, C. A., Maxwell, N. L., and Ward, D. L. 2008. Fungicide programs affect 'practical' resistance development in cucurbit powdery mildew of pumpkin. HortScience 43:1838-1845.

Wyenandt, C. A., McGrath, M. T., Rideout, S. L., Gugino, B. K., Everts, K. L., and Mulrooney, R. P. 2009a. Fungicide resistance management guidelines for cucurbit downy and powdery mildew control in the mid-Atlantic and Northeast regions of the United States. Crop Manag. 8. Online publication. doi.org/10.1094/CM-2009-0629-01-BR

Wyenandt, C. A., Rideout, S. L., Everts, K. L., Mulrooney, R. P., and Maxwell, N. L. 2009b. Development of a fungicide resistance management guide for vegetable growers in the mid-Atlantic states. Crop Manag. 8. Online publication. doi.org/10.1094/CM-2009-0316-01-MG 